\title{
Intellectual Capital, Knowledge Management, ICT and Employee Performance: A Literature Review
}

\author{
"M. Ihsan Abireza ${ }^{1}$, Riyan Mirdan Faris ${ }^{2}$ \\ ${ }^{1}$ Management Study Program, Faculty of Business and Humanities, Nusa Putra University, Indonesia \\ ${ }^{2}$ Management Study Program, Faculty of Business and Humanities, Nusa Putra University, Indonesia \\ *Corresponding email: ihsan.abireza_mn20@nusaputra.ac.id
}

\begin{abstract}
The systematic literature review has chosen the most viable and successful library strategy for this research. Capital refers to non-physical, intangible, or hidden assets (intangible assets) (invisible). Intellectual capital is a broad word that encompasses both human knowledge and experience and the technology used. In general, intellectual capital works to ascertain preferences for human resource operational operations inside an organization and raise the firm's value to boost stakeholder satisfaction. There is a significant positive association between Intellectual Capital and Employee Performance, meaning that, just as the capacity of the human brain cannot be fully defined, the organization as a whole is similarly unable of fully using the information it holds. Management of knowledge that affects employee performance.
\end{abstract}

Keywords: Intellectual Capital, Knowledge Management, ICT.

\section{INTRODUCTION}

Performance is a critical and fascinating component because it demonstrates the importance of its benefits; an institution wants employees to work honestly and to the best of their abilities to achieve high-quality work results; without a highquality performance from all employees, success in achieving goals will be impossible. Arduous to attain. Performance is defined as mental attitudes and actions that are always focused on the fact that the work being done now must be of more excellent quality than the work being done in the past and that the work being done in the future will be of a higher quality than today. An employee or employee will experience pride and pleasure in his or her accomplishments due to the performance he or she performs for the firm. In the realm of work, high performance is the desired state. An employee will receive positive job performance if he or she performs in line with established criteria, both in terms of quality and quantity.

According to [1], employee performance is the consequence of an employee's quality and quantity of performance in carrying out his activities in line with the obligations assigned to him. Motivation, competency, leadership, and work environment affect performance [2]. Work motivation, ability, work environment, discipline, leadership, and personality affect performance.

Additionally, due to the expanding relevance of intellectual capital in today's organizations, it has become a fascinating field of research. The traditional view holds that a company's valued assets include tangible assets such as land, labor, and capital, which are viewed as determinants of the company's financial performance. Intellectual capital, which consists of a business's unique resources and talents and is challenging to replicate and irreplaceable, can result in a competitive advantage and superior performance over businesses that do not utilize it.

Intellectual capital refers to non-physical, immaterial, or hidden assets. Intellectual capital is a broad word that encompasses both human knowledge and experience and the technology used. In the long run, intellectual capital has a significant impact on employee and organizational performance because organizations can use it to generate expected performance and as a tool for evaluating employee performance in order to develop employees who will survive the organization's future needs. Intellectual capital may benefit both organizations and society. 
Knowledge management is a term that refers to a system that was developed to help organizations create, document, classify, and share knowledge [1] According to [2] research, incomplete test results significantly influence the adoption of Knowledge Management's effect on employee performance. The success of an organization or company cannot be separated from the performance of employees. One of the efforts made by the company in maintaining employee performance is by implementing Talent Management and Knowledge Management. Talent Management within the company is beneficial to contribute to the company's performance.

Information technology has developed rapidly at this time. Information technology is a subset of technology that is used to handle data in a number of ways, including processing, acquiring, assembling, storing, and altering data to provide high-quality information, specifically information that is relevant, accurate, and timely. It can also be used for personal, business, and government purposes, providing strategic information for decision-making. According to [3] "Information technology is a set of tools that help you work with information and perform tasks related to information processing." Information technology is defined as a synthesis of computer and communication technologies.

Information technology has a very significant development in this era. Technology has been designed to support human work towards efficient, practical use. Technology that initially supported the fulfillment of production needs, now information technology helps manage organizational data and makes it easier to input data on buying and selling transactions. This can have an impact on productivity and employee performance in an organization or agency. Along with the rapid development of information technology, organizations are also required to compete competitively so that management needs can work effectively and efficiently. Following that, this study will conduct a literature analysis to ascertain the effect of intellectual capital, knowledge management, and ICT on employee performance.

\section{LITERATURE REVIEW}

\subsection{Employee Performance}

A business may be regarded as successful if its human resource performance aims to increase employee performance to meet the company's established goals. Performance refers to employees' accomplishments in carrying out assigned tasks. [4] defines performance as the outcome of someone's labor. According to [5], employee performance results from a person's work in terms of quality and quantity accomplished by workers while carrying out their assigned obligations. According to [6] performance is what workers do or do not do. Nevertheless, [7]

\subsection{Intellectual Capital and its influence on Employee Performance}

Intellectual capital, defined as a business's valuable, difficult-to-copy, and irreplaceable resources and abilities, may result in competitive advantages and superior performance over organizations that do not use. Intellectual capital may benefit both organizations and societ. Describe it as the knowledge and capacity for knowing that a social collectivity possesses. According to [8] ,intellectual capital is composed of three major components: first, human capital, which serves as an invaluable source of knowledge, skills, and competencies within an organization or business; and second, financial capital.

Intellectual capital has a significant impact on employee performance and, in the long run, organizational performance because it enables organizations to generate expected performance and evaluate employee performance in order to develop employees capable of meeting the organization's future needs.

\subsection{Knowledge Management and Its Effect on Employee Performance}

Knowledge management is a term that refers to a system that was developed to help organizations create, document, classify, and share knowledge [1] define knowledge management as "access to expertise, knowledge, and competence that allows new capabilities, improves performance, propels forward and innovation, and adds value to the client." [9] Describe knowledge management as a systematic application process for producing, collecting, organizing, and disseminating information inside businesses to increase productivity, reuse best practices, and minimize costs. Knowledge management is widely acknowledged as a critical tool for sustaining a competitive edge and enhancing performance [10]. Knowledge management has the impact of increasing staff performance and a company's competitive advantage. Rework is inefficient from job to job.

\subsection{ICT and Its Influence on Employee Performance}

ICT is a collection of instruments that assist humans in their daily activities. In this scenario, information will support the human effort. 
Additionally, conduct activities associated with information processing. ICT is a technology not limited to computer science, hardware, or software. Information will be processed and stored using this technique.

Additionally, this technology comprises communication technology to transmit or disseminate information. ICT encompasses all possible applications of technology. The objective is to transmit information via electronic means. [11] ICT is one of the instruments managers may employ to deal with change. The modifications in question, in this case, are those to information that has been processed and previously stored in a computer. ICT is a term that refers to a collection of computer technologies. The combination is made up of hardware and software components. The objective is to process, store, and disseminate data. Technology has been developed to assist humans in pursuing an efficient, practical application. Initially used to assist manufacturing demands, information technology today aids in managing organizational data and simplifies the entry of data on purchasing and selling activities. This is what can potentially affect an organization's or agency's productivity and personnel performance.

\section{RESEARCH METHODS}

\subsection{Review Method}

The most viable and successful strategy for conducting the literature review has been chosen for this study: a Systematic Literature Review (SLR). It covers the discovery, collecting, and critical analysis of several systematic research investigations. The primary objective of assessing this literature review approach is to offer an exhaustive summary of the current body of knowledge that is available and relevant to the research issue. It is intended to analyze and synthesize the best available evidence to produce evidence-based and valuable responses to a particular research issue. One of the primary reasons for selecting this research study is because SLR is the "gold standard" approach for investigating and synthesizing multiple studies on a subject. Additionally, SLR entails certain stages, such as defining a research topic, assessing available data, synthesizing its findings, and making applicable conclusions. This demonstrates that the pre-defined research topic on SE performance may be answered efficiently and methodically with the assistance of this type of literature study.

Additionally, the research study followed three distinct phases to correctly complete this literature review process. These procedures include determining the need to complete an SLR. SLR may be assisted correctly by taking into account all review methods, hence decreasing instances of research bias. This part considered the study selection method. The third stage is to evaluate the review methodology to make required modifications prior to reporting or executing the SLR phase.

\subsection{Research Questions}

The research questions considered in this study are as follows:

1) RQ1: What is the influence of intellectual capital on employee performance?

2) RQ2: What is the influence of knowledge management on employee performance?

3) RQ3: What is the influence of ICT on employee performance?

\subsection{Search strategy}

Regarding the study as mentioned above, the Boolean technique was used to collect relevant papers. The primary phrases associated with the research study and question are searched using Boolean operators in this search method. Among these operators are "AND" and "OR." On the other hand, the SLR's keywords include (intellectual) AND (capital) AND (knowledge), as well as (management) AND (knowledge) (computer OR technology OR ICT OR system).

\subsection{Study Selection}

All papers were derived from prominent digital sources, including "Google Scholar," to acquire accessible and credible material. Over 500 items were acquired via this approach. However, only the most recent articles that addressed the research questions were included, excluding the remainder from the SLR. The study included only papers published in Bahasa Indonesia; the remainder were excluded.

\subsection{Data Extraction, Quality, and Validity}

The selected papers have been extracted to elicit the most pertinent data about the above study topics. Each article followed the data extraction process, ensuring the study's quality and authenticity of the information acquired. Only original articles published in reputable journals were considered for this.

\section{RESULTS AND DISCUSSION}

\subsection{The influence of intellectual capital on employee performance}


Table 1. The influence of intellectual capital on employee performance

\begin{tabular}{|c|c|c|}
\hline No & Author (Year) & Results \\
\hline 1. & {$[12]$} & $\begin{array}{l}\text { Intellectual capital is used to identify preferences for human resource operational tasks } \\
\text { inside an organization and raise the organization's value to boost stakeholder } \\
\text { satisfaction. }\end{array}$ \\
\hline 2. & [13] & $\begin{array}{l}\text { Employee performance is positively correlated with intellectual capital and work } \\
\text { happiness, and employee loyalty is positively correlated with intellectual capital, job } \\
\text { satisfaction, and employee performance at four-star hotels in Bandung. Thus, } \\
\text { optimizing intellectual capital, work happiness, and staff performance is necessary. }\end{array}$ \\
\hline 3. & [14] & $\begin{array}{l}\text { Intellectual and spiritual intelligence are interconnected and affect employee } \\
\text { performance. }\end{array}$ \\
\hline 4. & [15] & $\begin{array}{l}\text { Employee performance is positively impacted by intellectual capital in a major way. The } \\
\text { following are the consequences of this research: 1) The mere presence of Intellectual } \\
\text { Capital in a business is sufficient to alter the performance of its employees, such that } \\
\text { the more effectively the business manages its Intellectual Capital, the greater the } \\
\text { productivity created by the business. } \\
\text { 2) The management of the company must enhance the capability of its human } \\
\text { resources (human capital) and select competent human resources in order to create } \\
\text { significant added value for the company, complete the supporting infrastructure } \\
\text { (structural capital) necessary to support the functioning of human resources, and } \\
\text { maintain and further improve good relationships between the company and its internal } \\
\text { and external partners (relational capital), Thus, if the value of Intellectual Capital is } \\
\text { enhanced, the value of Physical Capital will also grow. }\end{array}$ \\
\hline 5. & [16] & $\begin{array}{l}\text { That all of the study's hypotheses have been demonstrated to be significant. Employee } \\
\text { performance is positively impacted by intellectual intelligence, emotional intelligence, } \\
\text { and leadership. The most significant factor is emotional intelligence. The research } \\
\text { concludes that intellectual intelligence, emotional intelligence, and leadership all have } \\
\text { a critical role in boosting employee performance, either individually or collectively. }\end{array}$ \\
\hline 6. & [17] & $\begin{array}{l}\text { 1a. Because arithmetic > table }(3.230>1.996) \text { with a } 0.05 \text { significance level, Ho is } \\
\text { rejected, and } \mathrm{Ha} \text { is allowed, indicating that intellectual intelligence affects the } \\
\text { performance of PT. PLN Klaten area. 2. Because tcount > ttable }(4.167>1.996) \text {, Ho is } \\
\text { rejected and } \mathrm{Ha} \text { is approved, intellectual intelligence affects PT. PLN Klaten area } \\
\text { performance. }\end{array}$ \\
\hline
\end{tabular}

\subsection{The Effect of Knowledge Management on Employee Performance}

Table 2. The effect of knowledge management on employee performance

\begin{tabular}{|c|c|l|}
\hline No & Author (Year) & \multicolumn{1}{|c|}{ Results } \\
\hline 1 & {$[18]$} & $\begin{array}{l}\text { At the Batu City Transformer Center, talent management and knowledge } \\
\text { management positively and significantly impact performance. }\end{array}$ \\
\hline
\end{tabular}




\begin{tabular}{|c|c|c|}
\hline 2 & [19] & $\begin{array}{l}\text { Additionally, the study's findings demonstrate that the accepted premise is that talent } \\
\text { management and knowledge management together have a good influence on PT } \\
\text { Mahati Karawang's staff performance. Say }\end{array}$ \\
\hline 3. & [20] & $\begin{array}{l}\text { Employee performance is positively impacted by leadership, knowledge } \\
\text { management, and company culture. }\end{array}$ \\
\hline 4. & [21] & $\begin{array}{l}\text { With a significant value of } 0.00 \text { less than } 0.05 \text {, organizational culture and knowledge } \\
\text { management influence employee productivity. Employees are increasing the } \\
\text { importance of understanding knowledge management within a company. }\end{array}$ \\
\hline 5. & [22] & $\begin{array}{l}\text { Knowledge management has a significant impact on employee performance, } \\
\text { knowledge management has a significant impact on competitive advantage, and } \\
\text { employee performance significantly impacts competitive advantage. }\end{array}$ \\
\hline 6. & [23] & $\begin{array}{l}\text { With a significant value of } 0.00 \text { less than } 0.05 \text {, organizational culture influences } \\
\text { employee productivity. }\end{array}$ \\
\hline 7. & [24] & $\begin{array}{l}\text { If management and organizational learning substantially impact career development, } \\
\text { then knowledge management and career development must likewise have a } \\
\text { substantial impact on employee performance. Additionally, career development } \\
\text { serves as a buffer between knowledge management and organizational learning, as } \\
\text { well as their effect on employee performance. }\end{array}$ \\
\hline 8. & [19] & $\begin{array}{l}\text { The study's findings indicate that the widely accepted theory is that talent } \\
\text { management and knowledge management combined positively influence PT Mahati } \\
\text { Karawang's workers' performance. }\end{array}$ \\
\hline 9. & [21] & $\begin{array}{l}\text { The researcher can then justify the interpretation that } \mathrm{Ha} \text { is acceptable or that } \\
\text { Knowledge Management }(\mathrm{X}) \text { affects employee performance }(\mathrm{Y}) \text {. This research proves } \\
\text { that Knowledge Management held by the company is very effective in improving } \\
\text { employee performance which will also advance the company. }\end{array}$ \\
\hline 10. & [25] & $\begin{array}{l}\text { At Grand Dian Hotel Brebes, supervision and knowledge management have a } \\
\text { substantial beneficial influence on staff performance. }\end{array}$ \\
\hline 11. & [26] & $\begin{array}{l}\text { As a result of the research, it is clear that all independent factors, namely Knowledge } \\
\text { Management, Skills, and Attitude variables, have a considerable beneficial influence } \\
\text { on employee performance. }\end{array}$ \\
\hline
\end{tabular}

\subsection{The Influence of ICT on Employee Performance}

Table 3. The influence of ICT on employee performance

\begin{tabular}{|c|c|l|}
\hline No. & Author (Year) & \multicolumn{1}{c|}{ Results } \\
\hline 1 & [27] & $\begin{array}{l}\text { Employee performance at PT Pegadaian Denpasar is affected by employee ability to } \\
\text { operate information technology in 2015. With tcount=6.504>ttable=2.010 or a p-value } \\
\text { of } 0.000=0.05, \text { employee locus of control and ability to operate information } \\
\text { technology affect employee performance at PT Pegadaian Denpasar in } 2015 .\end{array}$ \\
\hline 2. & {$[5]$} & $\begin{array}{l}\text { PT. Asuransi Jiwasraya Pontianak has successfully provided information technology } \\
\text { media to assist employees in their job. According to the findings obtained for the } \\
\text { variables wireless information technology }(\mathrm{X} 1) \text { and wireline information technology }\end{array}$ \\
\hline
\end{tabular}




\begin{tabular}{|l|l|l|}
\hline (X2), it can be inferred that to fulfill the eligibility requirements for use as a research \\
3.
\end{tabular}

Intellectual capital is an intangible asset that, when used effectively, can help a business increase its advantage and competitiveness. Intellectual Capital is a way to combine intangible assets, property intellectual property, people, and infrastructure that enable the company to perform its functions properly. Intellectual Capital encompasses all employee knowledge as well as the capacity of the business to provide value and gain a competitive edge.

According to [8] intellectual capital is the product of the organization's three primary components: human capital, structural capital, and physical capital, all of which are related to knowledge and technology and are capable of providing added value to the business in the form of competitive advantage. This view is consistent with that of [31] who recognized three primary components of intellectual capital: human capital (HC), structural capital (SC), and physical capital (PC) (CE).

Employee performance is positively impacted by intellectual capital in a major way. In general, intellectual capital identifies preferences for human resource operational operations inside an organization and raises the firm's value to boost stakeholder satisfaction. The following are the consequences of this research: Because the mere presence of Intellectual Capital in a business is sufficient to influence employee performance, the more effectively a business manages its Intellectual Capital, the greater the productivity created by the business.
Management of knowledge that affects staff performance. Knowledge management is an attempt to maximize the value of an organization's intellectual property by developing, storing, disseminating, and applying knowledge in order to accomplish organizational goals. According to its definition, knowledge management is defined as knowledge obtained from individuals (individuals), which is typically obtained through experience, such as work experience in other companies; with sufficient experience, it will be easier to comprehend any differences in the environment. within the company. According to [9], knowledge management is the systematic process of capturing, structuring, managing, and disseminating knowledge throughout an organization in order to enable employees to work more efficiently, reuse 'best practices,' and reduce high project costs. According to [32] the foundation of knowledge management is that because humans cannot describe the brain's full capability adequately, the organization is similarly incapable of fully utilizing the information it possesses. Essentially, knowledge management is a subjective process that is difficult to communicate. There is a strong correlation between knowledge management and employee performance, knowledge management, competitive advantage, and employee performance and competitive advantage. Because competition frequently occurs between individuals, we must process our knowledge effectively if we wish to gain an advantage over other individuals.

Additionally, career development acts as a buffer between knowledge management and 
organizational learning on employee performance. Furthermore, if management and organizational learning substantially impact career development, then knowledge management and career development must likewise have a substantial impact on employee performance. Additionally, career development acts as a buffer between knowledge management and organizational learning on employee performance. Furthermore, if management and organizational learning substantially impact career development, then knowledge management and career development must likewise have a substantial impact on employee performance. Additionally, career development acts as a buffer between knowledge management and organizational learning on employee performance.

ICT is a type of system that tries to make human labor easier. ICT will evolve in lockstep with the advancement of global technology. ICT is also a broad umbrella of terminology encompassing any technological devices used to process and transmit data. Technology is a facility or system designed to enhance the user's comfort and convenience. Thus, technology is critical in the modern period, particularly with the rapid growth of digital technology, which influences employee performance.

Employee performance is positively impacted by technology, information, and communication. Demonstrates that if every employee utilizes one of the information technology systems effectively, employee performance outcomes will improve. Employee motivation has a substantial beneficial influence on performance. This demonstrates that if every person is motivated at work, this positively influences employee performance results. The quality of information technology systems deployment, their use, and employee faith in information technology all substantially impact employee performance. The use of technology enables employees to handle data more efficiently, access it more quickly, and boost their efficiency. Employees will perform better as a result of their trust in technology.

Employees who can utilize existing information technology will increase their performance. According to [33], for information technology to have a good effect on individual performance, it must be used effectively and be compatible with the job being supported. evaluated the influence of information technology on process output and performance quality in [34]. According to the findings of this study, information technology has a beneficial influence on production and performance quality. Demonstrate this in resourcebased information technology in [34].

\section{CONCLUSION}

Intellectual property, employees, and infrastructure that enable businesses to run correctly. Intellectual Capital is an intangible asset that, when properly utilized, may grow in value. According to numerous researchers, intellectual capital is the sum of the results of the organization's three primary components, namely human capital, structural capital, and physical capital, all of which are related to knowledge and technology and can contribute to the company's added value in the form of competitive advantage. In general, intellectual capital identifies preferences for human resource operational operations inside an organization and raises the firm's value to boost stakeholder satisfaction. Employee performance is positively impacted by intellectual capital in a major way. The assumption of knowledge management is that, just as people are unable of fully explaining the capability of the brain, the organization as a whole is equally incapable of adequately using the information it contains. Management of knowledge that affects staff performance. ICT is a type of system that tries to make human labor easier. Technology is a facility or system designed to enhance the user's comfort and convenience. Thus, technology is critical in the modern period, particularly with the rapid growth of digital technology, which influences employee performance. This demonstrates that if every person is motivated at work, this positively influences employee performance results. Employees will perform better as a result of their trust in technology. Employees who can utilize existing information technology will increase their performance.

\section{REFERENCES}

[1] L. Widayana, "Knowledge Management: Meningkatan Daya Saing Bisnis," Malang Bayumedia Publ., 2005.

[2] I. T. Anggapraja, "Pengaruh Penerapan Knowledge Management dan Pengembangan Sumber Daya Manusia terhadap Kinerja Karyawan PT Telkom Tbk. (Studi Explanatory Survey pada Karyawan Unit Human Capital Management PT Telkom Tbk.)," J. Apl. Manaj., vol. 14, no. 1, pp. 140-146, 2016.

[3] A. dan T. Kadir, "Teknologi Informasi Dan Komunikasi Dalam Globalisasi Pendidikan," Shautut Tarb. Ilmu-Ilmu Sos. dan Keislam., vol. 27, no. 2, pp. 142-157, 2012.

[4] S. Sutrisno, "Struktur modal: Faktor penentu 
dan pengaruhnya pada nilai perusahaan," $J$. Siasat Bisnis, vol. 20, no. 1, pp. 79-89, 2016.

[5] D. Fitriani, “Analisis Pengaruh Penggunaan Teknologi Informasi Terhadap Kinerja Karyawan PT. Asuransi Jiwasraya Pontianak," CogITo Smart J., vol. 4, no. 1, p. 171, 2018.

[6] R. L. Mathis, "Manajemen Sumber Daya Manusia," Salemba Empat, 2006.

[7] M. Robbins, P. Stephen Coutler, "Human Resources Management," Salemba Empat, no. Edisi 16, p. Jilid 1, 2016.

[8] T. Sawarjuwono, "Intellectual Capital: Perlakuan, Pengukuran Dan Pelaporan," $J$. Akunt. dan Keuang., vol. 5, no. 1, pp. 35-57, 2003.

[9] H. Nonaka, I. and Takeuchi, "The Knowledge-Creating Company: How Japanese Companies Create the Dynamics of Innovation," Oxford Univ. Press. New York, 1995.

[10] A. Nasser H. Zaied, G. Soliman Hussein, and M. M. Hassan, "The Role of Knowledge Management in Enhancing Organizational Performance," Int. J. Inf. Eng. Electron. Bus., vol. 4, no. 5, pp. 27-35, 2012.

[11] K. C. Laudon and J. P. Laudon, Management Information Systems 13th edition: Managing the Digital Firm. Prentice Hall.

[12] H. Helmiatin, "Optimalisasi Peran Modal Intelektual Terhadap Kinerja Karyawan," Etikonomi, vol. 14, no. 1, pp. 51-68, 2015.

[13] D. J. Priansa and L. Cahyani, "Pengaruh Modal Intelektual Dan Loyalitas Pegawai Customer Services Hotel Berbintang Empat di Kota Bandung," J. Ecodemica, vol. 3, no. 2, pp. 455-463, 2015.

[14] P. S. O. Siahaan, "Pengaruh Kecerdasan Intelektual (Iq) Dab Kecerdasan Emosi Terhadap Kinerja Karyawan," J. Penelit. Akunt., vol. 1, no. 1, pp. 1-14, 2019.

[15] M. Hidayat and D. F. Azzahra, "Pengaruh Intellectual Capital Terhadap Kinerja Karyawan di PT Bosowa Propertindo Makassar," J. Econ. Manag. Account. Technol., vol. 2, no. 1, pp. 12-21, 2019.

[16] P. D. Eka, “Analisis Pengaruh Kecerdasan Intelektual, Kecerdasan Emosional dan kepemimpinan terhadap Kinerja Karyawan (Studi Pada PT Bank BTN Cabang Ciputat)," Pendidikan, Ekon. dan Bisnis, vol. 1, no. iv, pp. 53-63, 2017.

[17] Y. S. Putri, "Pengaruh Kecerdasan Intelektual, Kecerdasan Emosional, Dan Lingkungan Kerja Terhadap Kinerja Karyawan Pt. Pln Persero Area Klaten," $J$. Stud. Manaj. Organ., vol. 13, no. 1, p. 88, 2016.

[18] K. Kardo, S. Wilujeng, and D. Suryaningtyas, "Pengaruh Manajemen Talenta Dan Manajemen Pengetahuan Terhadap Kinerja Karyawan Di Transformer Center Kabupaten Batu," J. Ris. Mhs. Manaj., vol. 6, no. 1, pp. 1-7, 2020.

[19] S. S. Nugrahatamala and D. A. Fadili, "Pengaruh Manajemen Talenta dan Manajemen Pengetahuan Terhadap Kinerja Karyawan," J. FEB UNMUL, vol. 23, no. 1, pp. 39-45, 2021.

[20] T. Pambudi, D. Ningsih, and T. Taufiqurrahman, "Pengaruh Kepemimpinan, Manajemen Pengetahuan Dan Budaya Organisasi Terhadap Kinerja Karyawan Pada Pt. Pelabuhan Indonesia (Persero) I Cabang Kota Dumai," J. Online Mhs. Fak. Ekon. Univ. Riau, vol. 4, no. 1, pp. 779-793, 2016.

[21] H. Teguh, "Pengaruh Manajemen Pengetahuan Terhadap Kinerja Karyawan di PT .," vol. 2, no. 2, pp. 1363-1371, 2021.

[22] M. Chaidir Ali, "ANALISIS PENGARUH MANAJEMEN PENGETAHUAN TERHADAP KINERJA KARYAWAN SERTA DAMPAKNYA PADA KEUNGGULAN BERSAING,” 2019.

[23] E. Sukarmanto et al., "Related Party Transaction Memperkuat Pengaruh Political Pusat Penerbitan Universitas," Kaji. Akunt., vol. 21, no. 2, pp. 126-141, 2020.

[24] J. Monica and M. Pramesti, "Pengujian Pecking Order Theory terhadap Perusahaan Surplus Non Keuangan di Bursa Efek Indonesia," J. Manaj. Teknol., vol. 16, no. 2, pp. 185-196, 2017.

[25] L. Baety, Jumi, and Taviyastuti, "Analisis Pengaruh Pengawasan Dan Manajemen Pengetahuan Terhadap Kinerja Karyawan Menggunakan Metode Regresi Berganda," Pros. Semin. Nas. Terap. Ris. Inov., vol. 6, no. 2, pp. 155-163, 2020. 
[26] A. Latief, N. Nurlina, E. Medagri, and A. Suharyanto, "Pengaruh Manajemen Pengetahuan, Keterampilan dan Sikap terhadap Kinerja Karyawan," Jupiis J. Pendidik. Ilmu-Ilmu Sos., vol. 11, no. 2, p. 173, 2019.

[27] N. K. E. D. Puspitayanti, I. M. Nuridja, and I. A. Haris, "Pengaruh Locus of Control dan Kemampuan Mengoperasikan Teknologi Informasi Terhadap Kinerja Karyawan Pada PT Pegadaian (Persero) Denpasar Tahun 2015," J. Pendidik. Ekon. Undiksha, vol. 5, no. 1, 2015.

[28] I. R. Shintia and A. Riduwan, "Pengaruh Sistem Informasi Akuntanis, Motivasi Kerja, dan Pemanfaatan teknologi informasi terhadap kinerja karyawan," J. Ilmu dan Ris. Akunt., vol. 10, no. 3, 2021.

[29] N. M. A. A. Kasandra and G. Juliarsa, "Pengaruh Kualitas Penerapan Sia, Pemanfaatan Dan Kepercayaan Teknologi Informasi Pada Kinerja Karyawan," EJurnal Akunt., vol. 14, no. 1, pp. 539-547, 2016.

[30] W. Triyani, B. Mahmudi, and A. Rosyid, "Pengaruh Pertumbuhan Aset Terhadap Nilai Perusahaan Dengan Profitabilitas Sebagai Variabel Intervening (Studi Empiris Perusahaan Sektor Pertambangan Yang Terdaftar Di Bursa Efek Indonesia Periode 2007 - 2016," Tirtayasa Ekon., vol. 13, no. 1, p. $107,2018$.

[31] N. Bontis, K. William Chua Chong, and S. Richardson, "Intellectual capital and business performance in Malaysian industries," J. Intellect. Cap., vol. 1, no. 1, pp. 85-100, 2000.

[32] W. R. King, "An integrated architecture for the effective knowledge organization.," $J$. Knowl. Manag., no. 12(2), pp. 1367-1380, 2008.

[33] T. F. Jin, “Analisis Faktor-Faktor yang Mempengaruhi Pemanfaatan Teknologi Informasi dan Pengaruh Pemanfaatan Teknologi Informasi terhadap Kinerja Akuntan Publik," J. Bisnis dan Akunt., vol. 5(1), pp. 1 - 26, 2003.

[34] I. Ghozali, "Analisis Multivariate Lanjutan dengan Program SPSS.," Badan Penerbit Universitas Diponegoro., 2006. . 